\title{
Environmental Law Enforcement Based on Local Wisdom Banjarmasin City Community to Realize Sustainable Environmental Awareness
}

\author{
Harpani Matnuh ${ }^{1}$, Dedy Ari Nugroho ${ }^{2 *}$ \\ 1,2 Universitas Lambung Mangkurat, Banjarmasin, Indonesia \\ Corresponding author. Email: dedy.nugroho@ulm.ac.id
}

\begin{abstract}
Bhinneka Tunggal Ika is the motto of the state, that represents the diversity and unity of the nation. Indonesia's diversity is a pride that contains challenges. Banjarmasin as one of the regions in Indonesia, has different characteristics from various aspects. Geographically, Banjarmasin city at an average altitude of $0.16 \mathrm{~m}$ below sea level with relatively flat area conditions. This condition resulted in banjarmasin city potentially inundated by water, especially in the condition of high tides and high rainfall. This article describes several aspects of environmental law enforcement as a means of preserving healthy environment until the future. The method used to compile this article is to use qualitative descriptions through literacy studies. The findings that can be described from this article, among others: (1) the quality of life the community is very determined from the aspect of legal awareness of the environment. (2) The government shall take 2 approaches to environmental law enforcement, namely dialogueist approach and legal approach. (3) Local wisdom that can be found in Banjarmasin city is functioning of the river as the center of the economy ranging from floating markets. Therefore, it is necessary to enforce environmental laws to achieve sustainable environmental preservation.
\end{abstract}

Keywords: Environmental Law, Community, Local Wisdom.

\section{INTRODUCTION}

South Kalimantan, as one of the provinces in Indonesia, is also known as the area of a thousand rivers. Management of river areas through community participation needs to be re-enforced. Johnson (2014: 765) states that active community participation carried out at the base or regional level illustrates the existence of a democratic system adopted by a country. In line with Johnson's statement, local communities living in river areas have more opportunities to participate in managing rivers so that their conditions are able to bring goodness in a sustainable manner.

Management of rivers and other environmental areas needs awareness and moral encouragement from the community managing it, this is important so that the management direction is in accordance with the interests and needs of the community (Sinukaban; 2007). This shows that the management of marine areas cannot be carried out by just one element in the community. But synergy with the government also needs to be pursued.

As a country that adheres to a democratic system, the power of the people in determining policies at the base level together with the government needs to be pursued. This is done through various activities to overcome environmental problems [1]. Community involvement needs to be facilitated and supported in the management of the river environment in order to bring about mutual benefits.

Based on the results of interviews with several community leaders, the Head of Rukun Tanga (RT 11 and 12) that community participation in river management is very low, this is due to the low social and economic status of the people along the Miai riverbank.

The commitment of the government and the community needs to be strengthened through awareness of participation. Community participation in the field of environmental management can be carried out on the 
aquatic environment. Local governments together with the community need to increase awareness of the aquatic environment to sustain life together in a sustainable manner [2].

The socialization of optimizing the community's role in river management will be carried out in Sungai Miai Village, North Banjarmasin District. In addition to helping the community at the base level, this activity is also a contribution to translating the contents of local regulations at the community level, especially in this case the community in Sungai Miai Village, Banjarmasin City.

One of the techniques used to save the river environment is a dialogical approach by providing information that is studied theoretically and practically [3]. The dialogue that will be carried out will produce something that is in line with the needs of the community regarding river management, in this case it will be carried out on the Miai River in Banjarmasin. Communities need to be educated so that they have a behavioral basis that is directed and can provide benefits. [4], provides a basis for the importance of government openness to access to information and empowerment in the community. In this case, it can be related to the role of the Miai River community in managing the river environment. On Tuesday with this statement, [5] provided information on the humanist approach that all stakeholders need to take so that the development and management of river areas runs well.

Strengthening public knowledge regarding environmental law enforcement regulations can improve the direction and orientation of structuring and saving the environment in Banjarmasin. The community is the key to the success of development and environmental management, because with the involvement of the community in environmental law enforcement, the government can accelerate the achievement of goals based on the legal awareness of the community. This article thoroughly explores efforts to strengthen community participation and through activities to strengthen legal knowledge of river management which will have an impact on providing access to participation in environmental management.

\section{THEORETICAL REVIEW}

\subsection{Community Participation}

Participation is on the agenda of democratic countries in various parts of the world. In line with this statement, [6] in his research journal said that participation is the main topic and agenda of many countries in the world, including mainland Europe. Participation is carried out involving public interests such as development policies, environment, health, social, and so on. Indonesia is one of the countries that recognizes and upholds participation, especially since Indonesia is a country that adheres to a democratic system. Community participation can strengthen democratic values in a country. [7] in his research, reveals that concerns about the declining legitimacy of democratic values, encourage every country to organize programs that allow public participation. Democratic values are deeply rooted in Indonesia and many programs enable public participation.

Regarding the notion of participation, [8] states that participation is the involvement of a person or community in self-determined change efforts. These changes are made in order to build themselves, build community, life and their environment through dialogue. The dialogue referred to by Mikkelsen is intended to make the community aware of the social impacts, advantages, and disadvantages of the implemented programs. Participation carried out by someone in the community, is often called social participation. [9] briefly explains that social participation is the involvement of people in society as a form of social responsibility to achieve the desired conditions.

Regarding the type or typology of participation, [10] gives an opinion about the type of community participation and its characteristics. According to Mardikanto, the type of participation and its characteristics can be observed in the following description.

a. Passive participation

Passive participation in the Mardikanto typology has certain characteristics, including: A person participates by first being given information, not because of his own awareness and knowledge;

b. Informative participation: someone participates by first explaining the intent and purpose. For example participation in answering questionnaire questions;

c. Consultative participation: someone participates by first conducting consultations on what and how to implement the program;

d. Material participation: someone participates, but expects compensation such as wages, food, and so on;

e. Functional participation

Someone participates by first forming a group to complete the program;

f. Self Participation

The community decides for themselves the technical, principle, and various matters related to the agreedupon program without any pressure from other parties; Community participation in realizing a healthy river area will encourage people to cultivate the value of clean living. The given participation encourages the emergence of other community motivations to do something more and sustainable. Every community can plan programs that will provide added value in terms of living and even material values if the river is managed properly. With the socialization to strengthen the role or participation of the community, it is expected to be able to make regional contributions related to the implementation of regional regulations and encourage people to have environmental awareness. 


\subsection{Local wisdom}

Understanding local wisdom Local wisdom is the identity or cultural personality of a nation that causes the nation to be able to absorb, even cultivate culture that comes from outside/other nations into its own character and abilities [11]. The identity and personality of course adapt to the views of the surrounding community so that there is no shift in values. Local wisdom is one of the means in cultivating culture and defending oneself from foreign cultures that are not good. Local wisdom is a view of life and knowledge as well as various life strategies in the form of activities carried out by local communities in responding to various problems in meeting their needs. In a foreign language, it is often conceptualized as a local policy of local wisdom or local knowledge "local knowledge" or local genius, [12]. Various strategies are carried out by the local community to maintain their culture. The same thing was also expressed by [13] Local wisdom is defined as a view of life and knowledge as well as a life strategy in the form of activities carried out by local communities in meeting their needs. Based on Alfian's opinion, it can be interpreted that local wisdom is a tradition and habit that has been carried out by a group of people from generation to generation which until now is still maintained by certain customary law communities in certain areas. Based on the above understanding, it can be interpreted that local wisdom can be understood as local local ideas that are wise, full of wisdom, of good value, which are embedded and followed by members of the community.

Furthermore, [14] is of the view that local wisdom is the way people behave and act in response to changes in the physical and cultural environment. A conceptual idea that lives in society, grows and develops continuously in people's awareness from those related to sacred life to the profane (daily part of life and is mediocre in nature). Local wisdom can be understood as local local ideas that are wise, full of wisdom, of good value, which are embedded and followed by members of the community. Local wisdom according to [15] is cement binding in the form of an existing culture so that it is based on existence. Local wisdom can be defined as a culture created by local actors through an iterative process, through internalization and interpretation of religious and cultural teachings that are socialized in the form of norms and used as guidelines in everyday life for the community. Based on the opinions of the experts above, researchers can draw a common thread that local wisdom is an idea that arises and develops continuously in a society in the form of customs, rules/norms, culture, language, beliefs, and daily habits.

\subsection{Enforcement of the Environment}

Environmental law consists of two elements, namely the notion of law and the notion of the environment. Environmental law is divided into two parts, namely classical environmental law and modern environmental law. Classical environmental law, oriented to the use of the environment or use oriented, while modern environmental law is oriented to the environment. Modern environmental law, has characteristics in the form that include:

a. Environmentally oriented (Environmental oriented law),

b. The method is comprehensive-integral, and

c. Its nature is very broad (flexible) because it is affected by the fact that the environment as an "ecosystem" is always in dynamics.

\section{METHOD}

In this study, the researcher explains the research findings in a series of words that can describe the data based on facts. The type of qualitative research used in this study is a phenomenological descriptive research type. In this type of research, researchers describe the experience of human life about a phenomenon described by the participants. The phenomenological descriptive qualitative research design requires a strong philosophical foundation from the results of in-depth interviews [16].

There are two things that characterize descriptive research, including: (1) research is centered on an existing problem, (2) the direction of thought used in descriptive type research is to collect data, then describe (explain) and then analyze, the data obtained using interview research, observation, and study of relevant documents. The purpose of this type of descriptive research is to explain the nature of the individual, the state of an object, and the symptoms inherent in an object [17]. In connection with this research, the nature of the individual, the state of an object, and the phenomena studied lead to certain phenomena.

\section{RESULTS AND DISCUSSION}

4.1 Strategy and Approach of the Banjarmasin City Government to enforce environmental law with local wisdom perspective

The city of Banjarmasin has potential geographical and topographical conditions if managed properly. Community participation and compliance with Regional Regulation No. 15 of 2016 is the key to fostering public awareness about the environment in the Banjarmasin river area. The city of Banjarmasin has an area of $98.46 \mathrm{~km} 2$ and a population of approximately 715,733 people with a population density of $7,118.32$ people $/ \mathrm{km} 2$. The city of Banjarmasin is divided by a large river, namely the Martapura river and there are 190 tributaries with 120 river conditions that are still active, 70 rivers without names and 18 rivers have disappeared (https:// berita.banjarmasinkota.go.id). Based on the results of a field survey conducted on the presence of the Miai River in RT 11 and 12, it can be concluded that it is in a proper condition or cannot function properly because there has been narrowing, sedimentation and water pollution caused by the establishment of illegal buildings on the river, household waste. and family latrines. Public awareness of the function of rivers and clean water is quite high, but due to economic limitations, the role of the community in river management is not optimal. 
The strategies used by the local government to make the climate village program a success and provide opportunities for the community to participate are as follows. Strengthen the capacity of local governments to encourage community participation. Establish partnerships with relevant ministries/institutions, local governments, the business world, and non-governmental institutions. Government commitment. Improving the development and application of appropriate technology. Strengthening community capacity in implementing climate change adaptation and mitigation efforts. Encourage the creation of leadership at the community level. Disseminate the success of climate change adaptation and mitigation efforts at the local level. Encouraging optimization of potential sources of funding.

From some of the descriptions above, there are things that the Banjarmasin City Government does, namely carrying out activities with a dialogical and activity approach. The form of dialogue, the Banjarmasin City government is carried out by referring to open dialogue activities with the community to plan medium and longterm activities in terms of the environment. In this activity, the Banjarmasin City government also carried out legal guidance activities by explaining how programs should be carried out by referring to the provisions of environmental law. Open dialogue activities carried out, referring to development standards and materials on the need for environmental control laws.

\subsection{Local Wisdom of Banjarmasin City as a source of life that must be tried}

Local wisdom is something that is part of a culture that exists in a society that cannot be separated from the community itself, this local wisdom can be said to be a value that has local wisdom in Indonesia which has been proven to play a role in determining or playing a role in the progress of the community. According to Sibarani (in Daniah) Local Wisdom is a form of understanding that exists in regulating people's lives or what is commonly referred to as local wisdom.

Regarding local wisdom located in Banjarmasin, it will be sustainable if law enforcement is strengthened. Based on the research data, the following are local wisdom in Banjarmasin. One of the mainstay sectors of South Kalimantan Province is the fisheries and marine sector. South Kalimantan's fishery potential includes a coastline of $1,330 \mathrm{~km}, 1,000,000$ ha of public waters, 2,400 ha of ponds, 53,382 ha of ponds and 3,752 ha of minapadi/rice fields. South Kalimantan's fishery production in 2013 was $339,437,3$ tons, which consisted of capture fisheries of $241,704,2$ tons and aquaculture of 97,733.1 tons. Capture fisheries production at sea provides the largest contribution to the development of the fisheries and marine sector.

In general, South Kalimantan's fishery products are still mostly absorbed for domestic needs, causing the export marketing business of fishery products to still not develop properly. For this reason, local governments continue to encourage increased fishery production in various ways, such as providing training and procedures for catching fish with environmentally friendly methods, providing assistance in the form of fishing vessels, improving infrastructure and building marine product processing facilities, so that the results obtained are not only as a raw material but has become a processed product. The potential of waters and fisheries as described above can be maximized if legal education for the community can be enforced. Law enforcement needs to be encouraged so that aquatic products can support the economy and the welfare of society in general.

The potential in the area can be accelerated if it can maximize and use the potential of local wisdom by making water tourism, and so on, also balanced with awareness of environmental law.

\section{CONCLUSION}

The conclusion that can be drawn from this research is that the Banjarmasin City Government has sought to enforce the river environment law by taking approaches and strategies, including. Strengthen the capacity of local governments to encourage community participation. Establish partnerships with relevant ministries/institutions, local governments, the business world, and nongovernmental institutions. Government commitment and Improving the development and application of appropriate technology.

\section{REFERENCES}

[1] Aflizar, Desain Sistim Informasi Pengelolaan Daerah Aliran Sungai (DAS) Untuk Rehabilitasi dan Konservasi DAS Sumani Kabupaten Solok. Banjarmasin, 2008.

[2] T. Cech, Principles of Water Resources: History, Development, Management, and Policy, 2 ed. USA: John Wiley \& Sons, 2005.

[3] E. Aldrian, Budiman, dan M. Karmini, Adaptasi dan Perubahan Iklim di Indonesia. Pusat Perubahan Iklim dan Kualitas Udara Kedeputian Bidang Klimatologi, Badan Meteorologi, Klimatologi dan Geofisika. Jakarta, 2011.

[4] R. Farida, Pengajaran Membaca di Sekolah Dasar. Jakarta: Bumi Aksara, 2005.

[5] Firmansyah dan M. Sigit, Analisa Butiran Sedimen Pantai Goa China Malang Selatan. Malang: Fakultas Perikanan dan Ilmu Kelautan Universitas Brawijaya.

[6] Gasserro, P. et al., "Pharmacological Actions of Statins: A Critical Appraisal in the Management of Cancer," Pharmacol. Rev., vol. 64, no. 1, hal. 102-46, 2021. 
[7] C. Johnson, "Local civic participation and democratic legitimacy: evidence from england and wales," Polit. Stud., vol. 63, no. 4, hal. 765-792, 2014.

[8] Mikkelsen B, Metode Penelitian Partisipator \& Upaya Pemberdayaan Masyarakat. Yayasan Obor Indonesia, 2006.

[9] J. Hagman, A.Sa"11, T.Compagno, C.Piskur, "Yeast "Make-AccumulateConsume" Life Strategy Evolved as a Multi-Step Process That Predates the Whole Genome Duplication," PLoS One, vol. 8, no. 7, hal. 1-7, 2013.

[10] T. Mardikanto, Konsep-Konsep Pemberdayaan Masyarakat, 1 ed. Surakarta: UNS Press, 2010.

[11] E. A. P. Wibowo, "SINTESIS N-DOPED TIO2 DAN APLIKASINYA UNTUK PENURUNAN KADAR LOGAM Pb PADA IKAN DAN KERANG," vol. 1, Universitas Negeri Semarang, 2015, hal. 15-3.

[12] U. Fajarini, "Peranan Kearifan Lokal Dalam Pendidikan Karakter. Universitas Islam Negeri (UIN). Jakarta," UIN, 2014. .

[13] M. Alfian, "Potensi Kearifan Lokal dalam Pembentukan Jati Diri dan Karakter Bangsa," J. Int. Conf. Indones. Stud., vol. 25-435, 2013.

[14] F. N. Istiawati, "Pendidikan Karakter Berbasis NilaiNilai Kearifan Lokal Adat Ammatoa dalam Menumbuhkan Karakter Konservasi," Cendikia, vol. 10, no. 1, hal. 1-18, 2016.

[15] N. K. Ratna, Antropologi Sastra: Peranan Unsurunsur Kebudayaan. Yoyakarta: Pustaka Pelajar, 2011.

[16] J. W. Creswell, Research Design Qualitative, Quantitative, and Mixed Methods Approaches.third Edition, Terjemah, Achmad Fawaid, Research Design Pendekatan Kualitatif, Kuantitatif, dan Mixed. Yogyakarta: Pustaka Pelajar, 2016.

[17] Nazir. Moh, Metode Penelitian. Jakarta: Ghalia Indonesia, 1983. 